\title{
Corrosion Investigation of Rock Anchors Served over 10 Years in Underground Powerhouse of a Hydropower Station
}

\author{
Tao Yin, ${ }^{1,2}$ Xingsong Sun $\mathbb{D}^{2},{ }^{2}$ Yujie Wang, ${ }^{2}$ and Yufei Zhao $\mathbb{D}^{2}$ \\ ${ }^{1}$ College of Civil and Transportation Engineering, Hohai University, Nanjing 210098, Jiangsu, China \\ ${ }^{2}$ State Key Laboratory of Simulation and Regulation of Water Cycle in River Basin, \\ China Institute of Water Resources and Hydropower Research, Beijing 100038, China \\ Correspondence should be addressed to Xingsong Sun; sunxs@iwhr.com
}

Received 5 December 2021; Revised 9 January 2022; Accepted 21 January 2022; Published 22 February 2022

Academic Editor: Zhongchang Wang

Copyright $(\subset) 2022$ Tao Yin et al. This is an open access article distributed under the Creative Commons Attribution License, which permits unrestricted use, distribution, and reproduction in any medium, provided the original work is properly cited.

\begin{abstract}
With the wide application of prestressed anchors in high slopes, underground structures, and bridge projects, the corrosion problems of the anchor structure during the long-term service have demanded more attention. Because of the environmental impact and structural characteristics, anchor cable corrosion is almost inevitable. To obtain the corrosion status of the anchors that have served over 10 years in the underground chambers of a power station, a field investigation was performed. The environment aggressivity was evaluated, and the anchor corrosion was inspected during the investigation. The results show that the effect of groundwater and stray current on anchor corrosion is slight. The main cause of the severe corrosion of the anchor heads is the high temperature and humidity in the chamber. To better evaluate the corrosion tendency and corrosion degree of the anchor head, a corrosion rating method was proposed based on the principles of existing investigation methods and the actual corrosion situation of anchors observed on-site. It was proved that the rating method can effectively reflect the corrosion characteristics and determine the areas prone to corrosion. This field investigation suggests that a regularly scheduled investigation is of great significance and meaning for accurately obtaining the corrosion status, assessing the failure risk, and issuing an early warning.
\end{abstract}

\section{Introduction}

As an effective reinforcement method, prestressed anchors have been widely applied in high slopes, underground structures, and bridge projects [1-4]. The anchor cables in long-term service often confront corrosion problems because of the presence of water and oxygen in the environment. [5-7]. The corrosion may lead to the attenuation of the anchors bearing capacity, thereby affecting the structure safety and even causing accidents $[8,9]$. The investigation on the collapse of the Taiwan Nanfang'ao Cross-sea Bridge, which happened on Oct. 1, 2019 and caused 6 deaths and 13 injuries [8], indicated that the severely corroded cables at the lower end of the bridge anchors caused the cable bearing capacity to decrease sharply and break at the end under the vehicle load [8]. Similar accidents have also been reported in other projects [7]. These accidents have brought more attention to the corrosion of prestressed anchor cables and the corresponding engineering safety issues.

Although multiple anticorrosion measures were generally adopted in the design and construction of anchor structures, cable corrosion seems to be inevitable. The only difference for various structures is that the life from corrosion initiation to structure failure varies because of environmental conditions and the anticorrosion means. Corrosion is a development and accumulation process. In this process, a periodic corrosion site investigation is a feasible and effective method to obtain the service status of the anchor cable in service and prevent engineering failures.

Corrosion field investigation of steel in structures usually includes environmental investigations and the corrosion characteristics of steel. Such investigations are relatively common in reinforced concrete structures. The purpose of an environmental investigation is to evaluate the 
corrosiveness of the environment to the steel in the concrete, including the $\mathrm{pH}$, the content of corrosive ions- $\mathrm{SO}_{4}{ }^{2-}$ and $\mathrm{Cl}^{-}$- and the ionic conductivity of the concrete electrolyte. The measured values are then compared with the standards [10-12] to determine whether the steels are prone to corrosion [13]. The main method for evaluating the corrosion status of steel bars in concrete is the half-cell potentials test. The details of the method and the specified value are described in ASTM C876-09 [14] and JGJ/T 152-2008 [15]. The feasibility of the half-cell potential method in the durability investigation of concrete structures has been proved effective in numerous studies [13,16,17]. The above investigation methods are relatively full-fledged and have been published as specifications, however, these methods can only qualitatively evaluate the environmental corrosiveness and the probability of steel corrosion in concrete.

Field investigations and studies on the corrosion of anchor cable structures are rarely reported, and no guiding specifications have been formed. There is no consensus on the investigation methods. Parry-Davies and Knottenbelt conducted an investigation on the long-term performance of prestressed anchor cables that have been in service for many years in 8 projects in South Africa and proposed an investigation process, including specific anchor characteristics, environment, observations, and conclusions [18]. The investigation emphasizes the importance of the durability of the anchor cable, however, the description and evaluation of the anchor cable corrosion are not detailed enough. Weerasinghe and Anson investigated the conditions of prestressed anchor cables in a cavern environment that had been in service for 22 years and suggested the investigation plan of corrosion inspection (above and below the anchor heads), metallurgical and environmental investigation, and load assessment program [19]. Wang et al. conducted a study on the corrosion of anchor cables served for 3 to 20 years at four sites by exhuming or investigating [2]. The investigation included groundwater corrosivity, temperature, humidity, underground stray current, and anchor cable corrosion. All of these projects include environmental investigations and anchor cable corrosion investigations, and to a certain extent borrowed from the experience of field investigations on reinforced concrete structures. Because of the difference between the anchor cable and the reinforced concrete, the methods used in the reinforced concrete investigations cannot be directly applied to the anchor cable structure. In addition, although the investigations of the prestressed anchor cables can qualitatively reveal the corrosion during service, it is difficult to make an accurate assessment of its impact. There are no specifications and guidelines that can be used for reference. Therefore, more efforts are needed to advance the development of methods and technologies in anchor cable corrosion investigation.

In this paper, a corrosion field investigation was carried out on prestressed anchor cables that have served over 10 years in the underground chamber of a hydropower station. On the basis of existing technical methods, the investigation ideas containing both environment aggressivity and corrosion inspection are proposed. Specifically, the investigation includes groundwater, temperature, humidity, underground stray current, and corrosion inspection of anchor head. By establishing a classification method for the corrosion status of anchor heads and analyzing the relationship between environmental corrosivity and anchor head corrosion, the reliability and effectiveness of the field investigation program are discussed.

\section{Description of Investigation Site and Anchor Cable Design}

The investigation site of the project is the underground main powerhouse, main transformer room, and tailrace surge chamber of a hydropower station. The length, width, and height of the chambers are $175.0 \mathrm{~m} \times 27.4 \mathrm{~m} \times 74.45 \mathrm{~m}$, $134.8 \mathrm{~m} \times 16.5 \mathrm{~m} \times 46.8 \mathrm{~m}$, and $130.0 \mathrm{~m} \times 25.0 \mathrm{~m} \times 67.0 \mathrm{~m}$, respectively. The surrounding rock of the underground powerhouse is mainly composed of greenish-grey metamorphic sandstone and grey white metamorphic quartz sandstone, interspersed with grey-black sandy slate. The surrounding rock is generally a metamorphic sandstone and metamorphic quartz sandstone (74\%), with chiefly a medium-to-thick layered structure. To improve the stability of the surrounding rock of the chamber, a large number of anchor cables were installed for reinforcement during the excavation.

The main powerhouse and the main transformer room are completely with reinforced concrete after excavation, and the anchor cables installed cannot be observed. Thus, the field investigation was mainly conducted in the tailrace surge chamber (Figure 1). 602 prestressed anchor cables were used to reinforce the surrounding rocks of the chamber. Unbonded anchor cables were adopted, and their structure is shown in Figure 2. The designed locked force of the anchors is $1000 \mathrm{kN}, 1500 \mathrm{kN}$, and $2000 \mathrm{kN}$, with 7 steel strands, 10 steel strands, and 14 steel strands for each. The steel strand is $1 \times 7-15.2-1860$ [20].

According to the design, the length of the anchor cable is $20 \mathrm{~m}$ to $30 \mathrm{~m}$. The anchor head is composed of three bearing plates and an anchor plate (Figure 3). After the anchor cable was tensioned and locked, a layer of mortar was poured on the surface of the anchor head to resist corrosion (Figure 3). The thickness of the mortar cover layer shall be at least $10 \mathrm{~cm}$ as required.

Different from the design, the anchor head is equipped with a steel protective cap (Figure 4), which serves as an additional protective layer between the anchor head and the mortar layer.

After excavation of the tailwater surge chamber, the wall was lined with 100 to $200 \mathrm{~cm}$ thick reinforced concrete. The lining area includes the downstream sidewall, the left and the right end wall below the elevation of 1,264.00, and the upstream sidewall below the elevation of 1,267.00 (Figure 5). Therefore, the anchor heads located in the lining area are enclosed in the lining and cannot be observed on-site. Only 154 anchor heads that can be observed were investigated in detail, including 28 anchor heads on the upstream side wall, 28 on the downstream side wall, 8 on the left end-wall, 10 on the right end-wall, and 81 on the arch crown. 


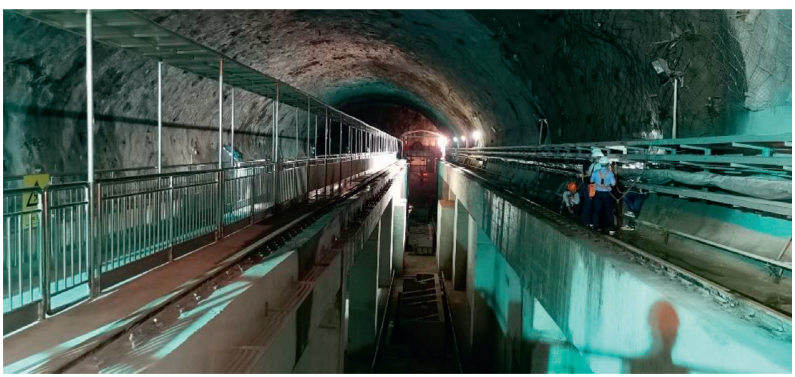

Figure 1: The field investigation in the tailrace surge chamber.

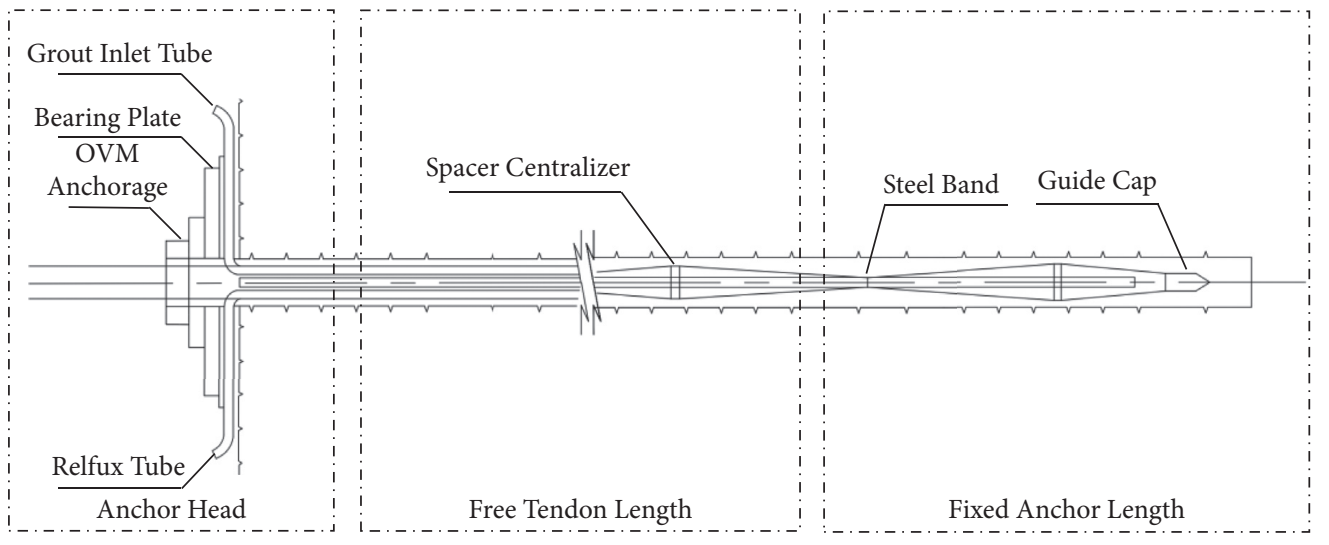

Figure 2: Design drawing of the anchor cable.

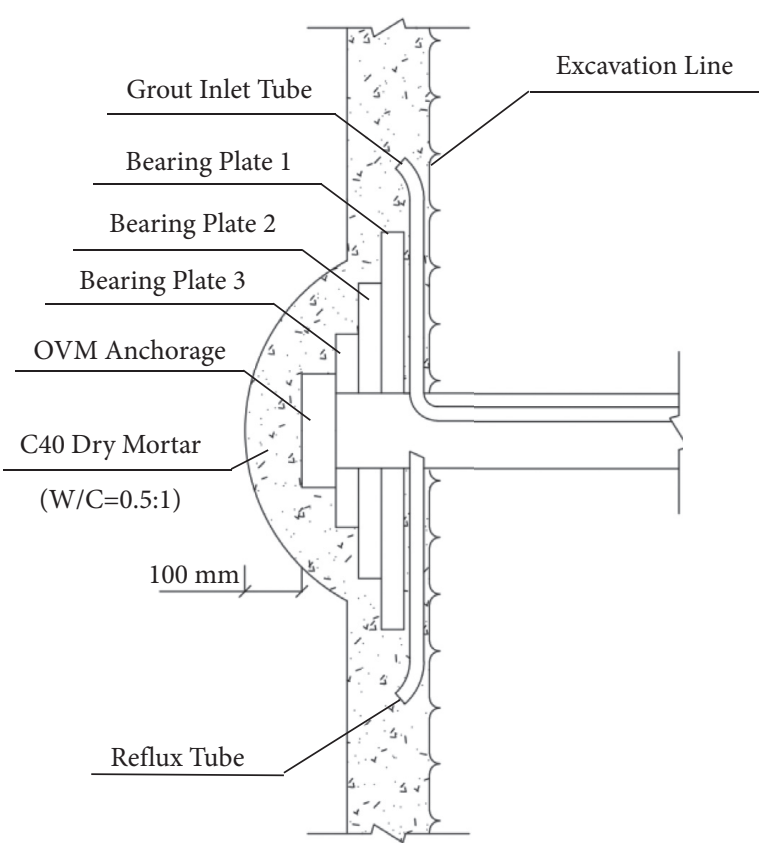

Figure 3: Design drawing of the anchor head.

\section{Environment Aggressivity Investigation}

3.1. Groundwater. Steel corrosion in underground engineering is related to the soluble salt content and $\mathrm{pH}$ in the groundwater. During the investigation, it was found that there was a groundwater seepage in the upstream sidewall of the tailwater surge chamber. The groundwater was sampled at the seepage point to analyze its corrosivity. The groundwater samples were carried out on the $1^{\text {st }}$ floor and the $2^{\text {nd }}$ floor drainage galleries near the tailrace surge chamber for comparison (Figure 6).

Based on the groundwater test results and specifications GB 50287-2016 [21] and GB 50487-2008 [11], the description of groundwater aggressivity in the tailrace surge chamber is descripted as shown in Table 1. The test results show that the groundwater is almost noncorrosive.

The test results of groundwater samples from drainage galleries near the tailrace surge chamber are shown in Table 2.

The water quality monitoring results of the groundwater samples from the underground main powerhouse near the tailrace surge chamber are shown in Table 3.

The groundwater in the tailrace surge chamber, drainage galleries and main powerhouse are slightly corrosive, which means the groundwater is not likely to cause serious corrosion of the anchor cable.

3.2. Humidity and Temperature. Metals are prone to corrosion in humid environments and the corrosion rate is directly related to temperature and humidity [22]. Therefore, the temperature and humidity in the environment are also important indicators for judging the corrosiveness of the environment. In the tailrace surge chamber, the temperature and humidity were measured at 4 chosen locations along the chamber axis. The Smart Sensor's Humidity \& Temperature 


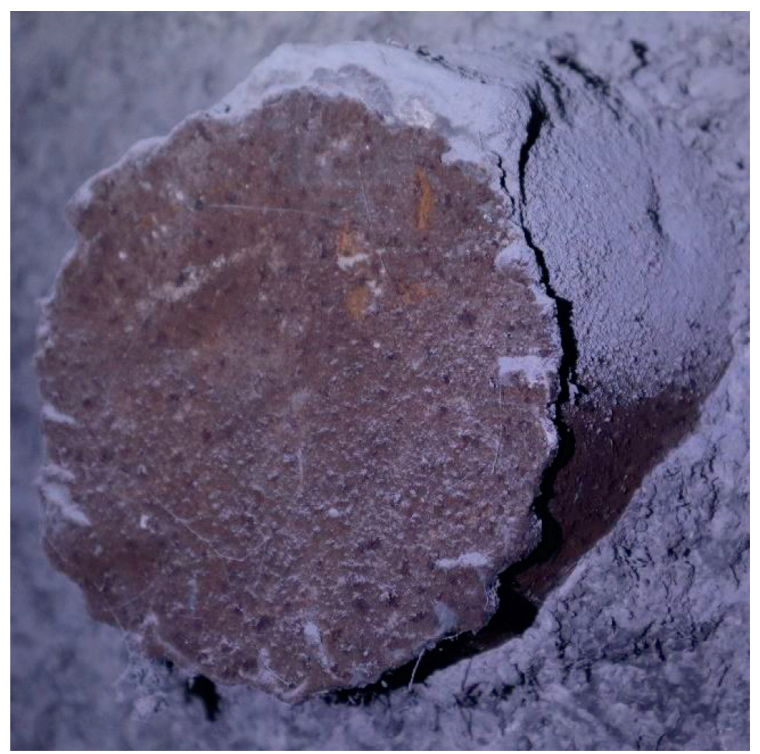

Figure 4: Protective cap on the anchorage top of the anchor head.

Meter (AS847) is used for testing (Figure 7). The results are shown in Table 4.

As shown in Table 3, the humidity in the tailrace surge chamber is $87 \%$ to $89 \%$, and the temperature is $24^{\circ} \mathrm{C}$ to $25^{\circ} \mathrm{C}$. In the atmosphere, the corrosion rate of metals generally increases with increasing humidity. For many metals, there is a critical humidity for corrosion, while the critical humidity for steel is around 65\% [22]. The highest relative humidity of the tailrace surge chamber is about $25 \%$ higher than the critical humidity, indicating that the relative humidity in the chamber has a great influence on corrosion. Thus, the tailrace surge chamber can be considered a severely corrosive environment.

3.3. Underground Stray Current. Stray current, which exists widely in rock and soil mass media, is another influencing factor of anchor corrosion. The action mechanism of the stray current is mainly based on the electrolysis of electrochemical corrosion [2]. High-tensile steel used in tendons is more sensitive to stray current corrosion than normal steel, and certain precautions are necessary in these structures where this type of corrosion may take place [23]. Because of the complexity of the anchor cable structure, it is difficult to accurately measure the potential. To determine whether there is a stray current in the surrounding rock of the tailrace surge chamber, the potential of the bolt installed in the rock was measured. The stray current test was conducted with a copper sulfate electrode, voltmeter, and wires (Figure 8). The stray current measurement results are shown in Figure 9.

As described in GB/T 21447-2018 [24], while the copper/ copper sulfate electrode (CSE) is used as the reference electrode, the metal is in a fully protected state when the potential is less than $-850 \mathrm{mV}$. When the potential is between $-850 \mathrm{mV}$ and $-650 \mathrm{mV}$, the metal is in a protected state. When the potential is between $-650 \mathrm{mV}$ and $-400 \mathrm{mV}$, the

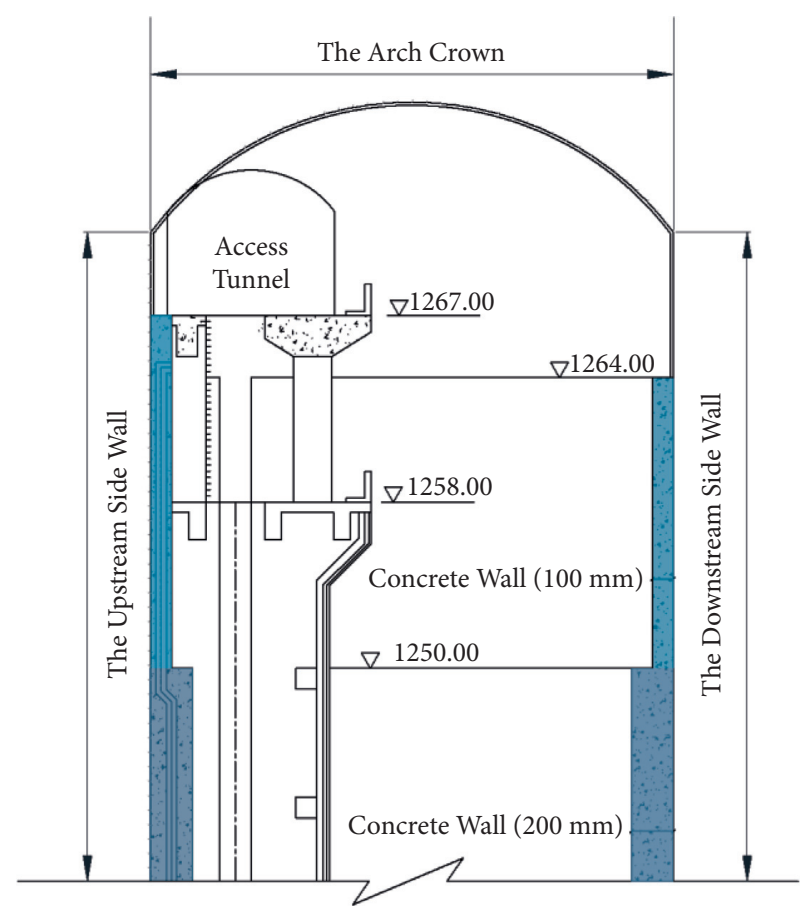

FIgURE 5: Cross-section of the tailrace surge chamber layout.

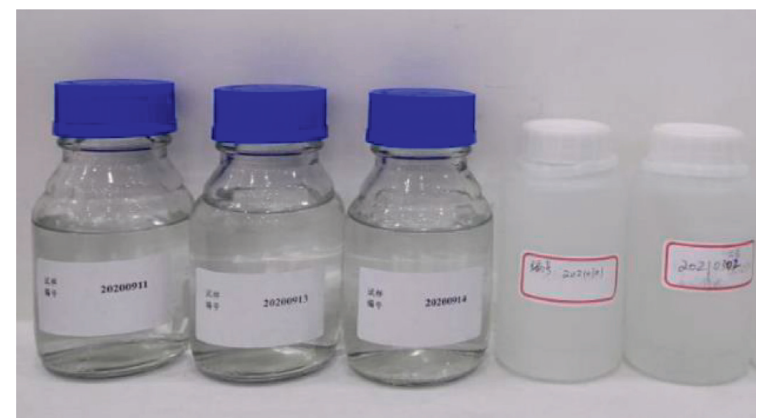

FIGURE 6: Groundwater samples from the tailrace surge chamber and adjacent drainage galleries.

TABLE 1: Groundwater aggressivity in the tailrace surge chamber.

\begin{tabular}{|c|c|c|c|}
\hline Item & Test value & $\begin{array}{l}\text { Standard } \\
\text { value }\end{array}$ & Description \\
\hline $\mathrm{HCO}_{3}^{-}$ & $2.07 \mathrm{mmol} / \mathrm{L}$ & $\begin{array}{c}>1.07 \mathrm{mmol} / \\
\mathrm{L}\end{array}$ & No dissolution corrosion \\
\hline $\mathrm{pH}$ & 8.35 & $>65$ & $\begin{array}{l}\text { No ge } \\
\text { co }\end{array}$ \\
\hline $\mathrm{Mg}^{2}$ & $\begin{array}{c}14.2829 \mathrm{mg} / \\
\mathrm{L}\end{array}$ & $<1000 \mathrm{mg} / \mathrm{L}$ & $\begin{array}{l}\text { No magnesium sulfate } \\
\text { corrosion }\end{array}$ \\
\hline $\mathrm{SO}_{4}{ }^{2-}$ & $21.945 \mathrm{mg} / \mathrm{L}$ & $<250 \mathrm{mg} / \mathrm{L}$ & $\begin{array}{l}\text { No magnesium sulfate } \\
\text { corrosion }\end{array}$ \\
\hline $\mathrm{Cl}^{-}$ & $2.462 \mathrm{mg} / \mathrm{L}$ & $<100 \mathrm{mg} / \mathrm{L}$ & Slight corrosion \\
\hline
\end{tabular}

metal is in a natural corrosion state. When the measured potential is greater than $-400 \mathrm{mV}$, there is stray current corrosion in the metal. As shown in Figure 7, Bolt7 and Bolt 10 have high potentials, however, they are still in the natural corrosion potential region. In general, half of the bolt potential is in the protected range, indicating that there should 
TABLE 2: Groundwater aggressivity in the drainage galleries near the tailrace surge chamber.

\begin{tabular}{lcccc}
\hline \multirow{2}{*}{ Item } & \multicolumn{2}{c}{$1^{\text {st }}$ floor gallery } & \multicolumn{2}{c}{$2^{\text {nd }}$ floor gallery } \\
& Sample 1 & Sample 2 & Sample 1 & Sample 2 \\
\hline $\mathrm{pH}$ & 7.41 & 7.75 & 7.86 & 7.99 \\
$\mathrm{HCO}_{3}{ }^{-}(\mathrm{mmol} / \mathrm{L})$ & 2.10 & 2.13 & 2.85 & 2.95 \\
$\mathrm{Mg}^{2+}(\mathrm{mg} / \mathrm{L})$ & 3.930 & 3.315 & 8.915 & 10.890 \\
$\mathrm{SO}_{4}{ }^{2-}(\mathrm{mg} / \mathrm{L})$ & 66.510 & 59.858 & 77.888 & 88.131 \\
$\mathrm{Cl}^{-}(\mathrm{mg} / \mathrm{L})$ & 14.679 & 9.986 & 14.724 & 17.628 \\
\hline
\end{tabular}

TABLE 3: Groundwater aggressivity in the underground main powerhouse.

\begin{tabular}{lcccc}
\hline Item & Time (year) & Test value & Standard value & Description \\
\hline \multirow{2}{*}{$\mathrm{HCO}_{3}{ }^{-}$} & 2018 & $2.61 \mathrm{mmol} / \mathrm{L}$ & $>1.07 \mathrm{mmol} / \mathrm{L}$ & \multirow{2}{*}{ No dissolution corrosion } \\
\hline \multirow{2}{*}{$\mathrm{pH}$} & 2019 & $2.59 \mathrm{mmol} / \mathrm{L}$ & $>6.5$ & No general acidic corrosion \\
\hline \multirow{2}{*}{$\mathrm{Mg}^{2+}$} & 2018 & 8.25 & $<1000 \mathrm{mg} / \mathrm{L}$ & \multirow{2}{*}{ No magnesium sulfate corrosion } \\
\hline \multirow{2}{*}{$\mathrm{SO}_{4}{ }^{2-}$} & 2019 & $25.28 \mathrm{mg} / \mathrm{L}$ & $<250 \mathrm{mg} / \mathrm{L}$ & No magnesium sulfate corrosion \\
\hline \multirow{2}{*}{$\mathrm{Cl}^{-}$} & 2018 & $50.60 \mathrm{mg} / \mathrm{L}$ & $<100 \mathrm{mg} / \mathrm{L}$ & \multirow{2}{*}{ Slight corrosion } \\
\hline
\end{tabular}

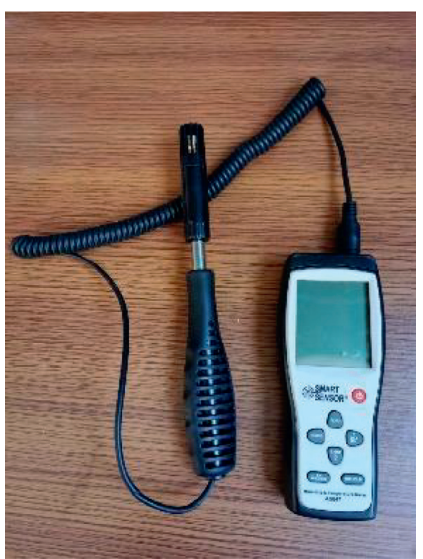

(a)

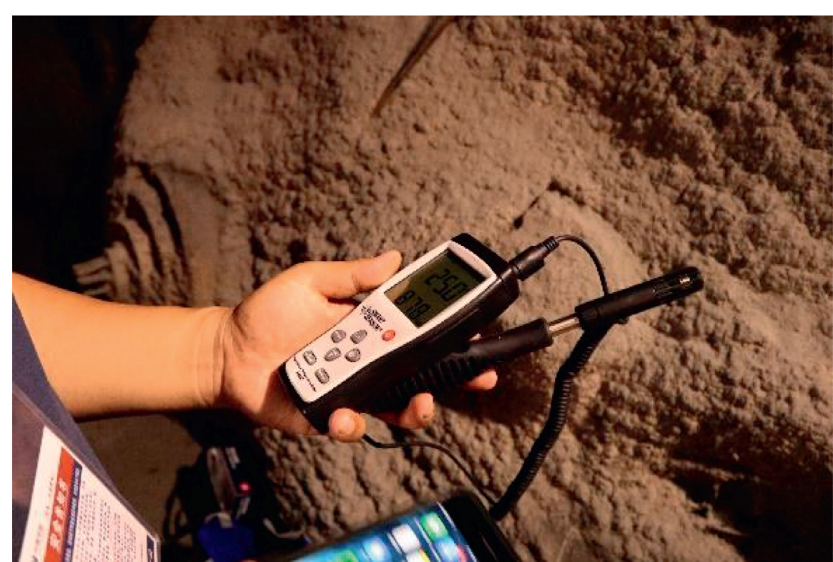

(b)

Figure 7: The Temperature and Humidity Measurement in the Tailrace Surge Chamber. (a) Humidity \& temperature meter. (b) Field measurement.

TABLE 4: Humidity \& temperature in the tailrace surge chamber.

\begin{tabular}{lcr}
\hline Test site & Humidity $(\%)$ & Temperature $\left({ }^{\circ} \mathrm{C}\right)$ \\
\hline 1 & 87.2 & 24.7 \\
2 & 87.8 & 24.1 \\
3 & 88.3 & 24.1 \\
4 & 87.8 & 25.0 \\
\hline
\end{tabular}

be no stray current in the rock near the tailrace surge chamber. In conclusion, the influence of the stray current on the anchor cable corrosion can be ignored in the chamber.

\section{Corrosion Inspection}

Both the free length and fixed length of the anchor cable are located in the rock mass, and only the anchor head may be observed. Hence, the corrosion inspection is carried out around the anchor head. According to the design requirements, mortar should be poured for sealing after the anchor head was installed (Figure 3). However, it was found in the field investigation that only some anchor heads are covered by mortar, while most anchor heads are exposed to the air partially or totally. Exposure may be caused by the cracking of the mortar layer arising from construction quality or the 


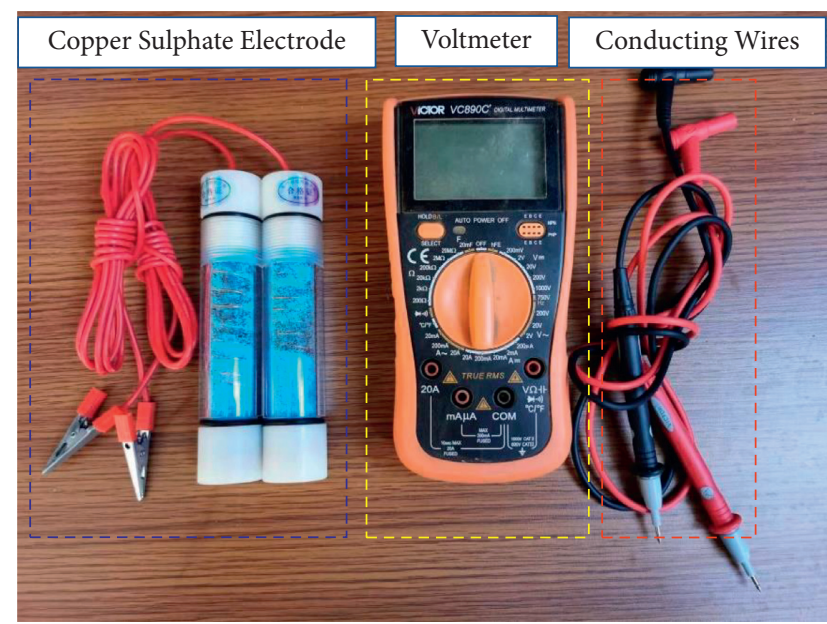

(a)

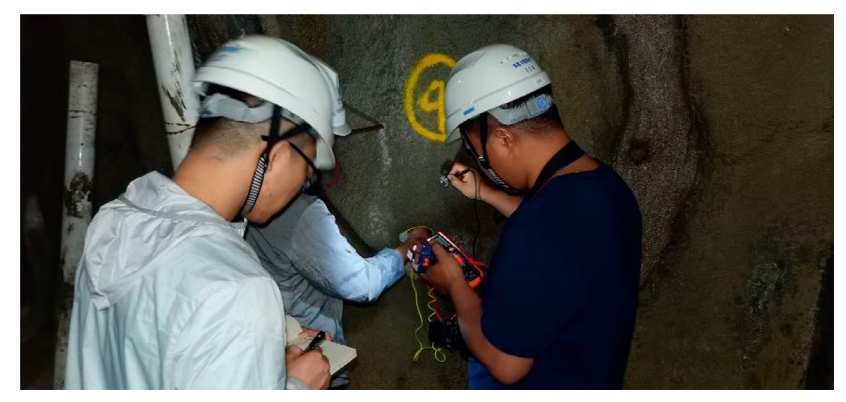

(b)

FIgURE 8: The stray current measurement. (a) The stray current measure device. (b) Field test.

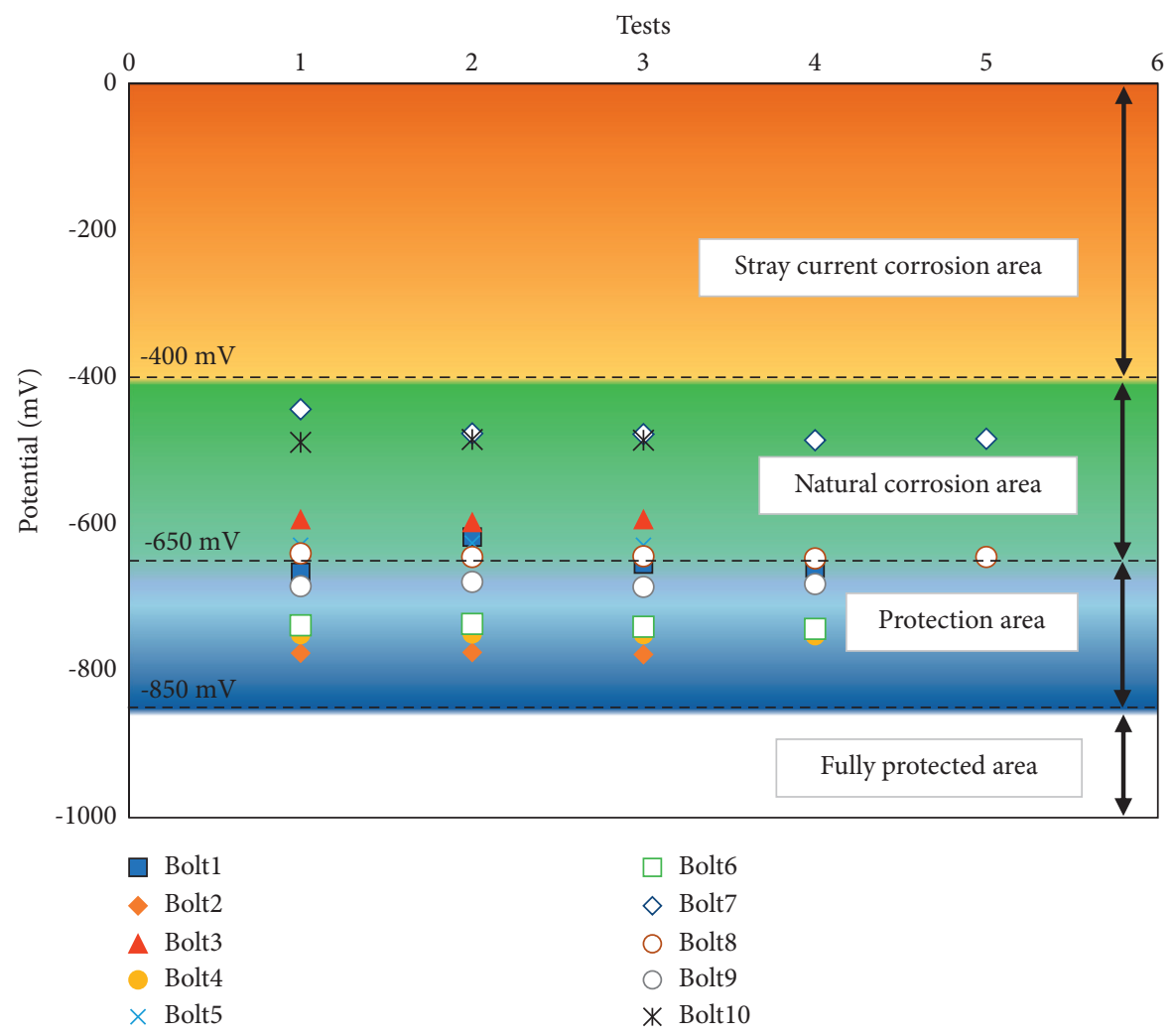

Figure 9: The stray current measurement results.

deformation of rocks. The anchor heads exposed to the corrosive environment formed different levels of rust and even severe rust in the local area (Figure 10).

To fully acquire the corrosion status of the anchor cable in the tailrace surge chamber, a set of new inspection procedure and evaluation system were proposed as described below.
4.1. Numbering and Investigation of Anchor Cables. The layout of anchor cables in the tailrace surge chamber was redrawn. The visible anchor heads were numbered to facilitate further record and description. The distribution of anchor cables on the left-end wall and the right-end wall is shown in Figure 11. 


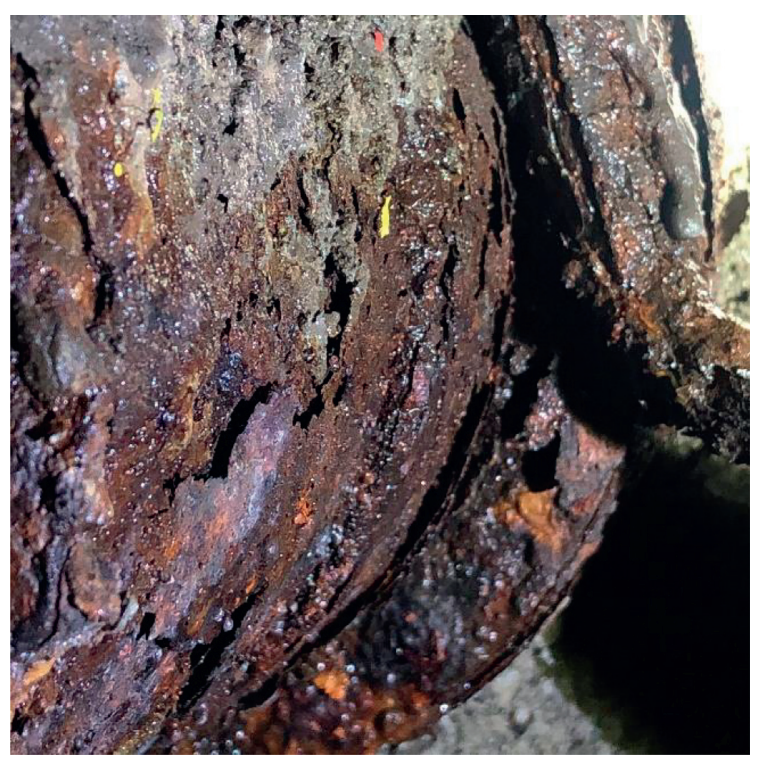

FIgURE 10: Severely rusted anchor head in the tailrace surge chamber.

4.2. Corrosion Description. Based on the above works, the anchor heads were visually inspected and photographed, and the exposure and corrosion status of anchor heads were recorded. Details are shown in Table 5. The dry environment in the table means that there is no observed water seepage or surface wetness.

4.3. Development of Guideline for Corrosion Inspection. The position and corrosion information of anchor heads were recorded in the field investigation. According to the field investigation results, most visible anchor heads in the tailrace surge chamber are partially or totally exposed, and they are rusted to different extents. Corrosion will affect the anchoring force of the cables. Accurately evaluating the corrosion degree of the anchor cable helps to assess its working performance. Therefore, it is of great practical significance that the working condition of anchor heads is rated from a corrosion perspective. Standard charts and specifications for qualitative rating are the ways that can be used for visual inspection and rating of metal corrosion currently.

4.3.1. Standard Charts for Corrosion Examination. To accurately evaluate the corrosion degree of metal, scholars have put a lot of efforts $[25,26]$. For example, Champion established the standard charts for metal corrosion evaluation in which the corrosion is classified into 7 degrees according to the density of rust spots, the rust area, and depth [25]. Similarly, the standard charts are used in ASTM G46 [26] to rate the corrosion degree of pitting with five grades in three aspects, including density, dimension, and depth, and the corresponding quantitative criteria are offered.

4.3.2. Specification for Qualitative Rating of the Corrosion Degree. Most specifications for rating the corrosion degree are qualitative. The methods in the specifications have been widely applied and rapidly developed because of the practicability and specific objects. Taking corrosion evaluation of bridge cable as an example, this qualitative evaluation method is elaborated.

The major means of evaluation on bridge cables are visual inspection. Hopwood \& Havens illustrated the importance of classification for steel wire corrosion and founded the corresponding rating standard [27]. With this standard, the corrosion degree of steel wire is classified into four types from the perspective of the consumption of the galvanized coating layer on the surface of steel wire (Table 6). Since this standard is relatively representative and used widely, Camo adopted it in his research [28].

West et al. [29] developed the corresponding rating and marking standards of prestressed steel wire, low carbon rebar, and tubes, respectively, in the research on corrosion resistance of bonded rebar in precast construction, which provided a standard for guiding evaluation on the corrosion degree.

Combining with the cable inspection experience of Chongqing Shimen Bridge, Xu [30] established a new set of corrosion degree rating standards for steel wire based on the works of Hopwood \& Havens [27] and West et al. [29]. This standard not only describes the corrosion degree of steel wire qualitatively but also establishes the corresponding minimum diameter of steel wire that can be used for calculating mechanical properties. Xu et al. [31] adopted this method on evaluating the corrosion condition of the dismantled cables in the reinforcement project of Yinpenling Bridge over the Xiangjiang River.

\subsubsection{Limitations of Existing Rating Standards of Corrosion} Degree Evaluation. Among existing rating methods of corrosion degree, the standard charts and the rating specifications have their own advantages. The standard chart quantifies the corrosion degree of metal with specified terms. Hence, it is more universal for different types of metal. However, this method is mainly for the laboratory. In a practical investigation, such scrutiny would result in a huge amount of work that is almost impossible to complete. On the contrary, the qualitative rating specification is more flexible in practical applications with high efficiency. Thus, to establish the method for the corrosion rating of anchor heads based on the above-mentioned standards, the accuracy and the feasibility should be taken into consideration. According to the field investigation results, exposure and corrosion degree of the anchor head should be considered for the corrosion rating of anchor heads.

4.4. Rating of Exposure of the Anchor Head. Corrosion factors, such as water, oxygen, and temperature, in the field are the essential elements that lead to the corrosion of the anchor head, while the exposure of the anchor head will speed up corrosion. The anticorrosion design is basically considered to be based on the isolation between the metal structure and the corrosive environment. Both the rating standards of Hopwood \& Havens [27] and $\mathrm{Xu}$ [30] took into consideration the galvanized layer on the surface of the steel 
WZ-1-2

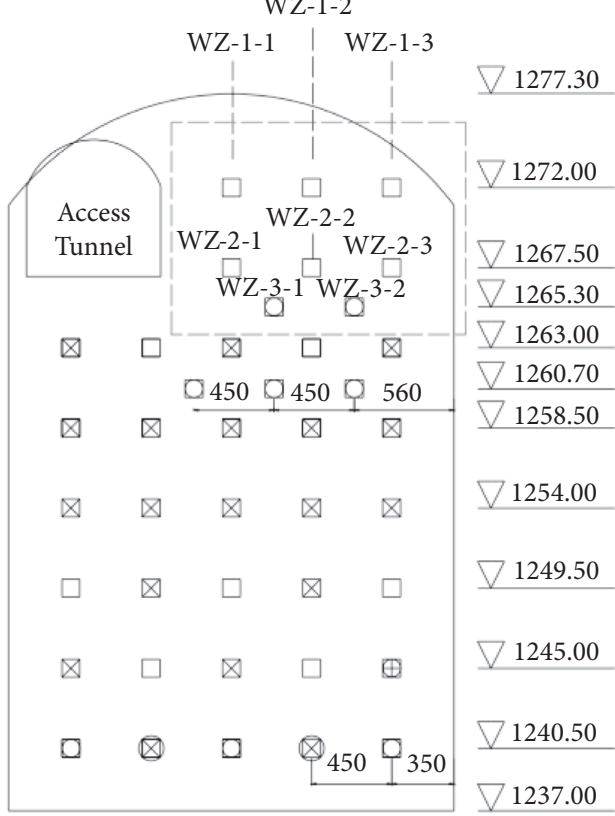

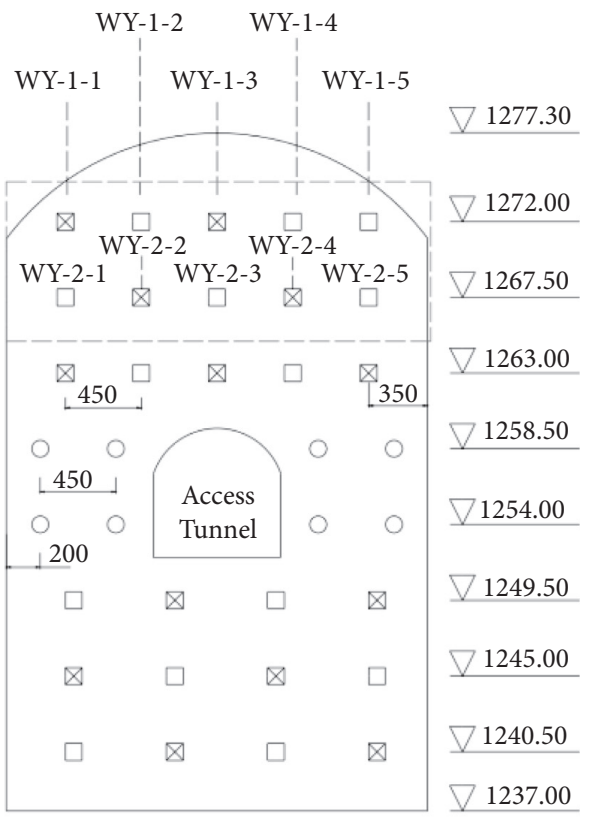

$\mid$

$1000 \mathrm{KN}, 12 \mathrm{~m}$

$1500 \mathrm{KN}, 20 \mathrm{~m}$

$\otimes 1500 \mathrm{KN}, 25 \mathrm{~m}$

(a)

(b)

Figure 11: Distribution and numbers of anchor cables on the left-end wall and the right-end wall of the tailrace surge chamber. (a) Left-end wall. (b) Right-end wall.

TABLE 5: Investigation record of anchor heads on left-end wall of the tailrace surge chamber.

\begin{tabular}{|c|c|c|c|}
\hline No. & $\begin{array}{l}\text { Position (left-end } \\
\text { wall) }\end{array}$ & Environment & Description of rust corrosion \\
\hline $\begin{array}{l}\text { WZ- } \\
1-1\end{array}$ & $\begin{array}{l}\text { Elevation } 1272.00 \mathrm{X} \\
0+123.5\end{array}$ & Dry & $\begin{array}{c}\text { The protective cap is exposed and free from damage, and it has obvious rust marks, } \\
\text { however, the rest of the parts are covered well }\end{array}$ \\
\hline $\begin{array}{l}\text { WZ- } \\
1-2\end{array}$ & $\begin{array}{l}\text { Elevation } 1272.00 \mathrm{X} \\
0+128.0\end{array}$ & Dry & $\begin{array}{l}\text { The protective cap is exposed partially and free from damage, and it has obvious rust marks, } \\
\text { however, the rest of the parts are covered well }\end{array}$ \\
\hline $\begin{array}{l}\text { WZ- } \\
1-3\end{array}$ & $\begin{array}{l}\text { Elevation } 1272.00 \mathrm{X} \\
\quad 0+132.5\end{array}$ & Dry & $\begin{array}{l}\text { The mortar layer is basically integral and has cracks, however, the anchor head structure is } \\
\text { not exposed }\end{array}$ \\
\hline $\begin{array}{l}\text { WZ- } \\
2-1\end{array}$ & $\begin{array}{l}\text { Elevation } 1267.50 \mathrm{X} \\
0+123.5\end{array}$ & Dry & $\begin{array}{l}\text { There is no protective cap, the ends of the small pat and the cable body are exposed locally, } \\
\text { the exposed part is obviously rusted, and the rest of the parts are covered by mortar well }\end{array}$ \\
\hline $\begin{array}{l}\text { WZ- } \\
2-2\end{array}$ & $\begin{array}{l}\text { Elevation } 1267.50 \mathrm{X} \\
\quad 0+128.0\end{array}$ & Dry & Integral mortar layer \\
\hline $\begin{array}{l}\text { WZ- } \\
2-3\end{array}$ & $\begin{array}{l}\text { Elevation } 1267.50 \mathrm{X} \\
\quad 0+132.5\end{array}$ & Dry & $\begin{array}{l}\text { The mortar layer is basically integral and has cracks, however, the anchor head structure is } \\
\text { not exposed }\end{array}$ \\
\hline $\begin{array}{l}\text { WZ- } \\
3-1\end{array}$ & $\begin{array}{l}\text { Elevation } 1265.30 \mathrm{X} \\
\quad 0+125.9\end{array}$ & Dry & $\begin{array}{l}\text { The whole anchor head is exposed, and there is mortar between cable bodies. The pad and } \\
\text { exposed cable body have obvious rust marks }\end{array}$ \\
\hline $\begin{array}{l}\text { WZ- } \\
3-2\end{array}$ & $\begin{array}{l}\text { Elevation } 1265.30 \mathrm{X} \\
0+130.4\end{array}$ & Dry & $\begin{array}{c}\text { The whole anchor head is exposed, the pad has obvious rust marks, and the mortar layer at } \\
\text { the ends of the cable body is integrate }\end{array}$ \\
\hline
\end{tabular}


TABLE 6: Evaluation and rating system for corrosion on wire (Hopwood \& Havens, 1984 [27]).

\begin{tabular}{|c|c|}
\hline Rating & Rating standard \\
\hline Stage 1 & Wire surfaces have a shiny metallic appearance, though some signs of white zinc corrosion product may be visible in spots. \\
\hline Stage 2 & $\begin{array}{l}\text { Wire surfaces dull as zinc corrodes. The wires eventually are covered with white corrosion product. However, there is no ferrous } \\
\text { corrosion under the white corrosion product. }\end{array}$ \\
\hline Stage 3 & $\begin{array}{c}\text { The signs of ferrous rust are visible on wire surfaces. Zinc coating is almost completely consumed. Random wire cracking is } \\
\text { possible in this stage. }\end{array}$ \\
\hline e 4 & $\begin{array}{c}\text { Ferrous rust stains or displaces most of the white corrosion product on wires. Wire surfaces become very rough and pitted. Wire } \\
\text { cracking is anticipated at this stage of deterioration }\end{array}$ \\
\hline
\end{tabular}

wire since the galvanized layer is used to prevent corrosion caused by a reaction between the steel wire and the environment. When the galvanized layer ages and peels off, the steel wire begins to corrode and the corrosion will be severer. The whole process is as follows: aging and peeling off of the galvanized layer, beginning of corrosion of the steel wire, severe rust, the crack of the steel wire, and the failure of the cable. The corrosion of the galvanized layer is directly classified into the corrosion of the steel wire in their rating standards.

Different from the galvanized steel wire, the anchor head is relatively complex, which is usually composed of the bearing plate, anchorage plate, steel protective cap, and cover layer-normally mortar or concrete. For the anchor head, the cover layer plays the same role as the galvanized layer. Different from the galvanized steel wire, the anchor head structure is much more complex. The bearing plate, anchorage plate, and the protective cap beneath the cover layer have different functions. Hence, the impacts of corrosion on the safety of anchors are different. The rust process of anchor heads because of the damage of the cover layer has three possibilities that can be summarized as follows: 1) damage to the cover layer, the rust of the protective cap, the rust of the anchorage plate, and the failure of the anchorage plate, 2) damage to the cover layer, the rust of the anchorage plate, and the failure of the anchor head, 3) the rust of the cover layer, the rust of the bearing plate, and the failure of the anchor head. Thus, during the rating of the anchor heads, the exposure situation of the structure shall be rated according to the breakage condition of the cover layer.

The components of the anchor head can be classified into the load-bearing structure and corrosion resistance structure. The load-bearing structure includes the bearing plate and anchorage plate, and the corrosion resistance structure includes a mortar and steel protective cap.

Thus, according to the functions and exposure conditions of the above-mentioned components, exposure can be classified into four ratings: A, B, C, and D. The details about the ratings are described in Table 7.

According to the above exposure ratings of the anchor head structure, when the grade is $\mathrm{A}$, it indicates that the protective structures work well. When the grade is $B$, it indicates that the cover layer is broken and the steel protective cap is exposed. When the grade is $\mathrm{C}$, it indicates that the protective structures of the anchor head are broken, and one of the bearing structures is exposed. When the grade is $\mathrm{D}$, it indicates that the protective structures of the anchor head fail, and both the anchorage plate and bearing plate are exposed.
TABle 7: Description of exposure ratings of the anchor head structure.

\begin{tabular}{lc}
\hline Rating & Rating standard \\
\hline A & Integrated cover layer \\
B & Exposed protective cap \\
C & Either anchorage plate or bearing plate is exposed \\
D & Both anchorage plate and bearing plate are exposed \\
\hline
\end{tabular}

4.5. Rating of the Corrosion Degree of Anchor Heads. The corrosion degree ratings of the steel strands of the suspended bridges cannot be directly used for evaluating the corrosion degree of anchor heads. It is almost impossible to perform detailed and accurate statistics of the quantity of rust spots and rust depth on anchor heads in field with the standard chart method. Anchor heads in service are not demountable, and rust cleaning for statistics may lead to structural damage. Thus, the rating of the corrosion degree of anchor heads is developed based on the principles of the abovementioned methods established by Champion [25], Hopwood \& Havens [27], West et al. [29], and $\mathrm{Xu}$ [30]. The developed five ratings are described in Table 8.

According to the above anchor head corrosion ratings, when the corrosion grade of the anchor head is level 0 , it indicates that the protective structures are integral and effective, and the structure is considered to be in a good condition without rust. When the corrosion grade of the anchor head is level 1, it indicates that the corrosion degree of the structure is slight. Corrosion only occurs on the local surface. When the corrosion grade is level 2, it indicates that the corrosion degree of the structure is moderate, and corrosion has completely developed. When the corrosion grade is level 3, it indicates that the corrosion degree of the structure is severe, and the corrosion has developed deep into the structure. When the corrosion grade is level 4 , it indicates that the corrosion degree of the structure is extremely severe, the anchor head components may lose their functions.

4.6. Application of the Rating Method. Based on photos and visual inspection records of the site, the exposure ratings (Table 9), corrosion degree ratings (Table 10), and the combined ratings (Table 11, Figure 12) of 154 anchor heads were carried out using the proposed rating methods stated in Tables 6 and 7.

As shown in Table 8, among 154 anchor heads in this survey, the anchor heads rated for A are only $11.69 \%$, and the anchor heads rated for $\mathrm{B}$ are $70.13 \%$, which is the most. 
TABLE 8: Description of corrosion ratings of the anchor head structures.

\begin{tabular}{lc}
\hline Rating & Rating standard \\
\hline 0 & No rust or cannot find rust \\
1 & Slight rust, local rust spots on the surface \\
2 & Obvious rust, rust spots on the whole surface \\
3 & Severe rust, with uneven surface because of rust \\
4 & Severe rust, with layered or peeling rust products \\
\hline
\end{tabular}

TABLE 9: Exposure ratings of the anchor head structure.

\begin{tabular}{|c|c|c|c|c|c|}
\hline \multirow{2}{*}{ Position } & \multirow{2}{*}{ Quantity (pcs.) } & \multicolumn{4}{|c|}{ Structure exposure ratings } \\
\hline & & A & $\mathrm{B}$ & $\mathrm{C}$ & $\mathrm{D}$ \\
\hline Upstream sidewall & 27 & 5 & 14 & 7 & 1 \\
\hline Downstream sidewall & 28 & 5 & 12 & 7 & 4 \\
\hline Left-end wall & 8 & 3 & 2 & 2 & 1 \\
\hline Right-end wall & 10 & 2 & 4 & 3 & 0 \\
\hline Arch crown & 81 & 3 & 73 & 5 & 0 \\
\hline Total & 154 & 18 & 105 & 24 & 7 \\
\hline Percent & $100.00 \%$ & $11.69 \%$ & $70.13 \%$ & $15.58 \%$ & $4.55 \%$ \\
\hline
\end{tabular}

TABLE 10: Corrosion ratings of anchor head structure.

\begin{tabular}{|c|c|c|c|c|c|c|}
\hline \multirow{2}{*}{ Position } & \multirow{2}{*}{ Quantity (pcs.) } & \multicolumn{5}{|c|}{ Corrosion degree rating } \\
\hline & & 0 & 1 & 2 & 3 & 4 \\
\hline Upstream sidewall & 27 & 5 & 1 & 11 & 0 & 10 \\
\hline Downstream sidewall & 28 & 5 & 2 & 12 & 0 & 9 \\
\hline Left-end wall & 8 & 3 & 0 & 5 & 0 & 0 \\
\hline Right-end wall & 10 & 2 & 1 & 4 & 1 & 2 \\
\hline Arch crown & 81 & 3 & 0 & 46 & 16 & 16 \\
\hline Total & 154 & 18 & 4 & 78 & 17 & 37 \\
\hline Percent & $100.00 \%$ & $11.69 \%$ & $2.60 \%$ & $50.65 \%$ & $11.04 \%$ & $24.03 \%$ \\
\hline
\end{tabular}

TABLE 11: Combined ratings of anchor heads structure.

\begin{tabular}{|c|c|c|c|c|c|c|c|}
\hline \multirow{2}{*}{ Combined rating } & \multicolumn{5}{|c|}{ Position } & \multirow{2}{*}{ Total } & \multirow{2}{*}{ Percent (\%) } \\
\hline & Upstream end wall & Downstream end wall & Left-end wall & Right-end wall & Arch crown & & \\
\hline A0 & 5 & 5 & 3 & 2 & 3 & 18 & 11.69 \\
\hline B1 & 0 & 0 & 0 & 0 & 0 & 0 & 0.00 \\
\hline B2 & 10 & 5 & 2 & 4 & 41 & 62 & 40.26 \\
\hline B3 & 0 & 0 & 0 & 0 & 16 & 16 & 10.39 \\
\hline B4 & 4 & 7 & 0 & 0 & 16 & 27 & 17.53 \\
\hline $\mathrm{C} 1$ & 1 & 0 & 0 & 1 & 0 & 2 & 1.30 \\
\hline $\mathrm{C} 2$ & 1 & 6 & 2 & 0 & 5 & 14 & 9.09 \\
\hline $\mathrm{C} 3$ & 0 & 0 & 0 & 1 & 0 & 1 & 0.65 \\
\hline $\mathrm{C} 4$ & 5 & 1 & 0 & 1 & 0 & 7 & 4.55 \\
\hline D1 & 0 & 2 & 0 & 0 & 0 & 2 & 1.30 \\
\hline D2 & 0 & 1 & 1 & 0 & 0 & 2 & 1.30 \\
\hline D3 & 0 & 0 & 0 & 0 & 0 & 0 & 0.00 \\
\hline D4 & 1 & 1 & 0 & 1 & 0 & 3 & 1.95 \\
\hline
\end{tabular}

There are $15.58 \%$ of the anchor heads that have one loadbearing structure exposed and $4.55 \%$ that have two loadbearing structures exposed. The above rating results indicate that only about $10 \%$ of the visible anchor heads in the tailrace surge chamber can meet the design requirement.

According to Table 10, half of the anchor head structures have been obviously rusted (Level 2). Nearly 1/4 of the anchor heads have been severely rusted (Level 4).
Table 11 shows the combined ratings of anchor heads in the tailrace surge chamber. It reveals that all the exposed anchor heads have different extents of rust. Figure 12 displays the anchor heads with different combined ratings.

To further discuss the spatial distribution of the corrosion degree of the anchor heads, the corrosion ratings of 0 to 4 are depicted with different colors on the anchor cable 

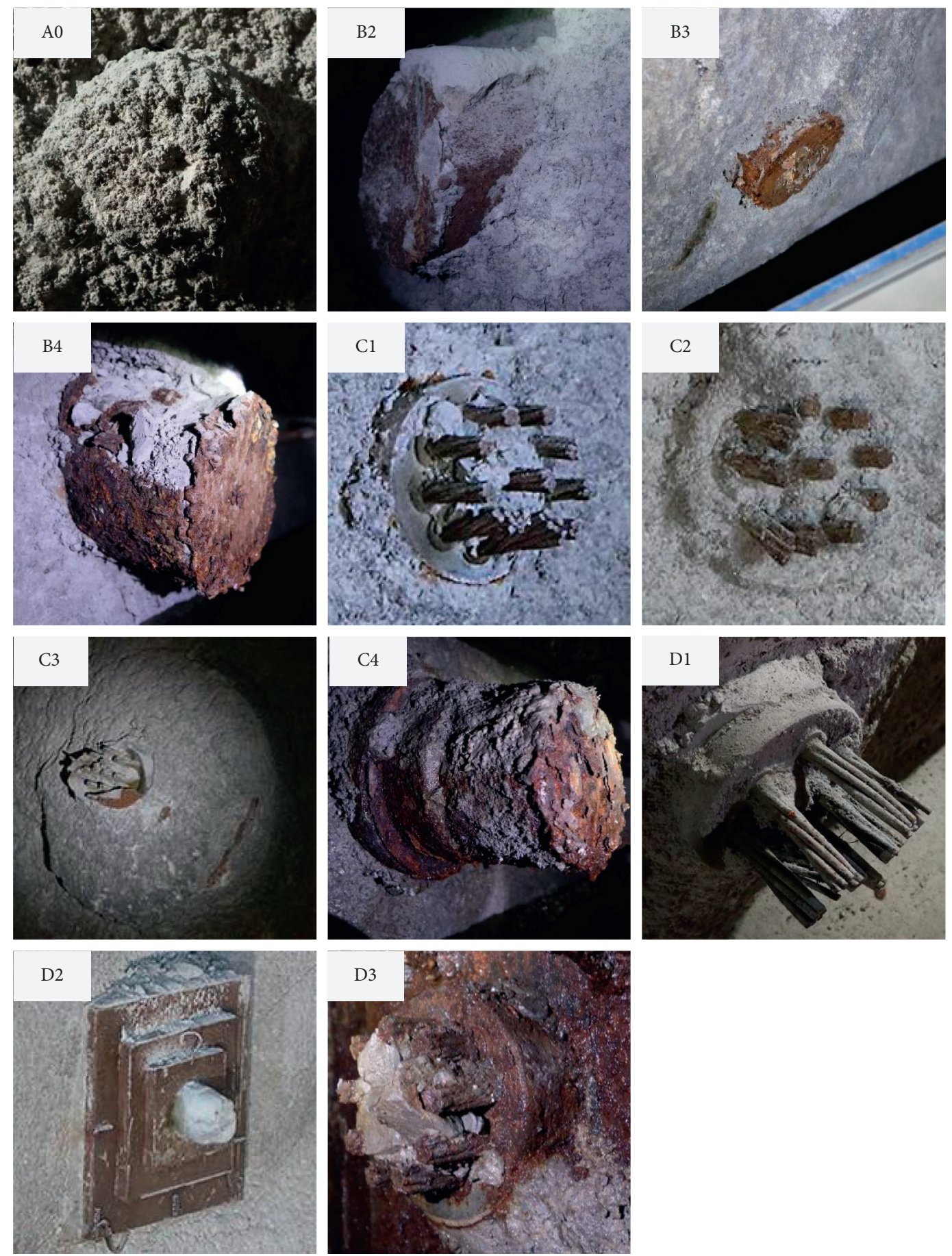

FIgURE 12: Anchor heads with different combined ratings.

layout drawing. Figure 13 shows the distribution of the corrosion degree of anchor heads on the upstream sidewall of tailrace surge chamber.

As shown in Figure 13, severely rusted anchor heads on the upstream sidewall are located between anchor WS-1-19 and anchor WS-1-24 with the elevation $1268.50 \mathrm{~m}$, and the pile number from Y $0+049.5$ to $\mathrm{Y}$ $0+027.0$. This corrosion degree is consistent with the geology conditions of the site that there is an F2 fault in this area (Pile No. Y $0+033.1$ ) according to the geological investigation report. The monitoring data also show a large deformation of the surrounding rock near the fault. The cover layer of nearby anchor heads was destructed gradually by the deformed surrounding rock in this area, resulting in the exposure of the anchor head components. The high humidity caused by the groundwater seepage through the fault sped up the corrosion of the anchor head. It also proved that the condition rating method of the anchor head established in this study was reasonable and reliable. 


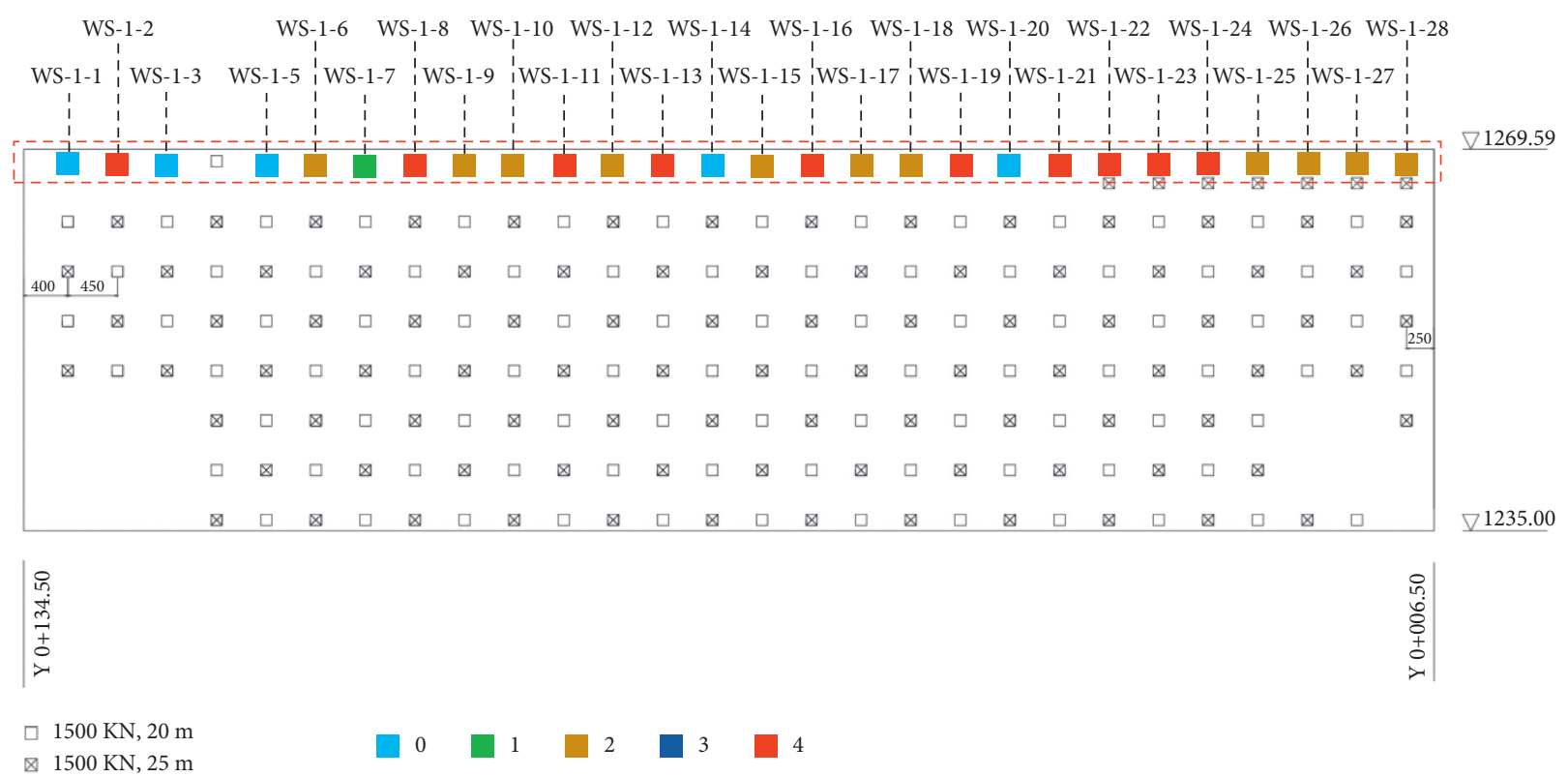

FIGURE 13: Distribution of corrosion degrees of anchor heads on the upstream sidewall of tailrace surge chamber.

\section{Discussion and Conclusion}

5.1. Correlation between Environment Aggressivity and Corrosion. The site inspection of the anchor cable in the tailrace surge chamber revealed that some metal parts of the anchors were exposed and corroded to varying degrees. According to the investigation results of environmental corrosivity, the groundwater in the chamber is slightly corrosive, and the influence of stray current in the rock mass can also be ignored.

Corrosion of the exposed anchor head is atmospheric corrosion. In the atmospheric corrosion of metals, humidity and temperature have a great influence. Humidity may cause a water film to form on metal surfaces and promote corrosion. As the humidity increases, the thickness of the water film will change significantly. For a smooth steel surface, when the relative humidity is $55 \%$, the thickness of the water film is about 15 molecular layers. When the relative humidity is near $100 \%$, the thickness of the water film will increase up to 90 to 100 molecular layers [22]. The critical humidity of steel is $65 \%$, and the corresponding water film thickness is 20 to 30 molecular layers. Above this humidity, the corrosion rate increases rapidly. The humidity of the tailrace surge chamber is about $88 \%$, and the thickness of the water film on the steel surface is 50 to 60 molecular layers, which is about twice the critical humidity. Therefore, humidity will accelerate the corrosion of the steel obviously. For the anchor head near the water seepage point, the humidity is higher, and the corresponding corrosion will be more serious.

In addition, the oxygen absorption corrosion of the anchor head is an electrochemical reaction process, and the increase in temperature will accelerate the reaction process, thereby accelerating the corrosion. As shown in Figure 14, the study conducted by Suzumura and Nakamura suggested that the corrosion rate of steel strands has a strong

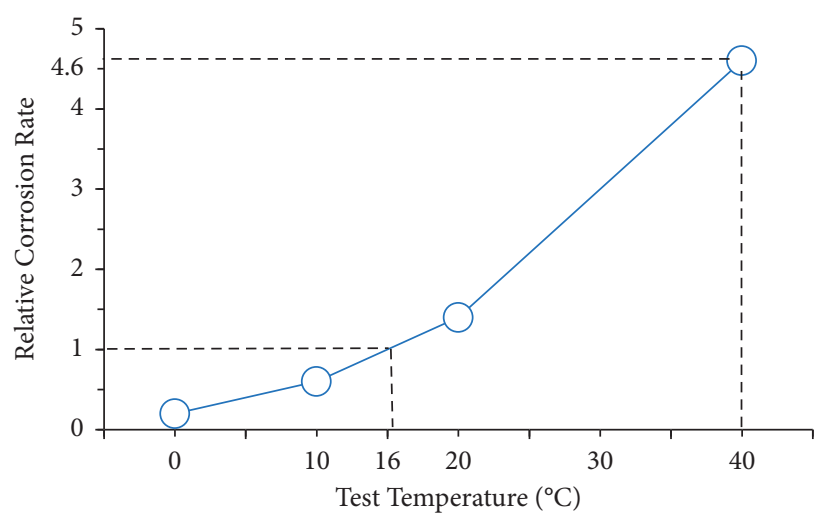

FIGURE 14: Correlation between temperature and relative corrosion rate [32], with permission from ASCE.

relationship with temperature [32]. As shown in the figure, for the average temperature of the external environment of $16^{\circ} \mathrm{C}$, the relative corrosion rate is 1 . However, the temperature detected in the chamber is close to $25^{\circ} \mathrm{C}$, and the corrosion rate of the anchor head is increased by 2.5 times compared to the external environment.

Based on the thermodynamic and kinetic theory, the oxygen corrosion of iron is a process of increasing entropy, which can occur in the presence of water and oxygen. The rate of oxygen corrosion is closely related to the concentration of reactants and temperature. The reactants concentration is mainly the content of water and oxygen. In a high humidity environment, a water film may form on the metal surface, providing electrolyte and water for the corrosion process. At the same time, the thickness of the water film formed on the steel surface is limited, and oxygen in the air can easily reach the steel surface through the water film and accelerate corrosion. In addition, the higher temperature will increase the corrosion rate constant of the chemical 
reaction. Therefore, the temperature and humidity in the environment have great effects on the corrosion of steel anchor heads.

For reinforced concrete and anchor cable structures, the current evaluation of environmental erosivity is less focused on temperature and humidity. For the anchor cable structure, because of the rock deformation, construction defects and atmospheric corrosion may occur in the anchor head and the free section near the anchor head. It is, therefore, necessary to include temperature and humidity in the corrosion investigation of the environment. In this investigation, the underground chamber environment is a slightly corrosive environment, while from the perspective of temperature and humidity, it is a severely corrosive environment. It also explains the serious corrosion of the anchor heads in the chamber.

5.2. Functions of the Rating Methods. Through the establishment of the rating method, the corrosion degree of anchor heads in the practical projects is clearly classified, which facilitates the implementation of reasonable treatments for different ratings of anchor heads. In this respect, engineering safety problems caused by the damage of anchor heads can be avoided, and their service life can be prolonged at a reasonable cost. For example, the exposure ratings of anchor head structures indicate that only $11.69 \%$ of the anchor heads are wrapped by an integral mortar cover layer, and the remaining anchor heads have different degrees of exposure. Therefore, it is suggested that remedial mortar or concrete pouring should be applied to existing exposed anchor heads to form an integral protective layer.

Corrosion degree ratings of the anchor head structure indicate that $50.65 \%$ of the anchor heads suffer obvious corrosion, and $24.03 \%$ of the anchor heads suffer severe corrosion. Severely rusted anchor heads should be marked, and the progress of the corrosion shall be investigated in routine inspection. According to the investigation results, $6.49 \%$ anchor heads suffer the exposure of the load bearing structure and severe corrosion (C4 and D4), which should be brought to the forefront and considered to be replaced or substituted.

With the anchor head corrosion rating method established in this study, the mechanical properties of anchor heads under each rating cannot be examined yet. Evaluation of the mechanical properties is equally significant for the maintenance of anchors. This work can be conducted by indoor experiments in the future to improve the utility of the rating method.

5.3. Conclusions. This paper investigated the corrosion of anchor cables that served for 10 years in an underground chamber of a hydropower station. The purpose of the investigation is to acquire the corrosion characteristics of anchor cables in the underground environment and to discuss the existing field investigation methods and their effectiveness. A new corrosion rating method for anchor cables is proposed. The conclusions are as follows:
(1) The influence of groundwater and stray current on corrosion is slight in the underground chamber environment.

(2) The temperature and humidity in the chamber environment are relatively high, which has strong corrosive effects.

(3) Most of the visible prestressed anchors in the chamber are partially exposed. The exposed anchor heads are corroded to varying degrees, and some of them are seriously corroded.

(4) The corrosion of the anchor head is highly related to the temperature and humidity in the environment.

(5) The proposed corrosion rating method of anchor heads can effectively reflect the corrosion characteristics and determine the areas prone to corrosion.

(6) The field investigation of corrosion can accurately obtain the corrosion status of anchor cables, discover the failure risk, and put forward an early warning.

\section{Data Availability}

The data used to support the findings of this study are available from the corresponding author upon request.

\section{Conflicts of Interest}

The authors declare that they have no conflicts of interest regarding the publication of this paper.

\section{Acknowledgments}

This research was funded by the National Key R\&D Project of China (Grant no. 2018YFC0407000), the National Natural Science Foundation of China (Grant nos. 51879284 and 52179121), and the Research Project of China three Gorges Corporation (Contract no. JG/19055J), the Science and Technology Project of China Huaneng Group (Grant no. HNKJ19-H14).

\section{References}

[1] Y. Wang, A. Ren, Y. Wang, J. He, and Z. Chen, "Investigations on corrosion and mechanical properties of a 20 year old ground anchor exhumed at a power station site," Canadian Geotechnical Journal, vol. 53, no. 4, pp. 589-602, 2016.

[2] Y. Wang, X. Sun, and A. Ren, "Investigations of rock anchor corrosion and its influence factors by exhumations in four typical field sites," Engineering Failure Analysis, vol. 101, pp. 357-382, 2019.

[3] T. Yin, X. S. Sun, Y. J. Wang et al., "Corrosion characteristics of anchor cables in electrolytic corrosion test and the applicability of the test method in study of anchor cable corrosion," Advances in Civil Engineering, vol. 2021, Article ID 6695288, 11 pages, 2021.

[4] C.-H. Yoo, Y. C. Park, and H.-K. Kim, "Section loss in naturally corroded 7-wire steel strands in external tendons," Structure and Infrastructure Engineering, vol. 16, no. 11, pp. 1593-1603, 2020.

[5] F. Li, Z. Liu, Y. Zhao, Y. Qu, and R. Lu, "Experimental study on corrosion progress of interior bond section of anchor 
cables under chloride attack," Construction and Building Materials, vol. 71, pp. 344-353, 2014.

[6] F. Li, X. Luo, and Z. Liu, "Corrosion of anchorage head system of post-tensioned prestressed concrete structures under chloride environment," Structural Concrete, vol. 18, no. 6, pp. 902-913, 2017.

[7] X. Zeng, Z. Chen, j. Wang, and Y. Du, "Research on safety and durability of bolt and cable-supported structures," Chinese Journal of Rock Mechanics and Engineering, vol. 23, no. 13, pp. 2235-2242, 2004.

[8] H. H. N. Ma, F. T. K. Au, N. Mickleborough et al., Investigation Report on Prestressing Tendon Failure Incident at Concrete Viaduct of Shenzhen Bay Bridge - Hong Kong Section, Hong Kong Highways Department, Hong Kong, 2019.

[9] Taiwan Transportation Safety Board, Investigation Report on Major Transportation Accidents Part 1: Major Road Accident of Nanfangao Bridge Rupture (TTSB-HOR-20-11-001), Taiwan Transportation Safety Board, Taiwan, 2020.

[10] W. Elkey and E. Sellevold, Electrical Resistivity of Concrete, Norwegian Road Research Laboratory, Oslo, Norway, 1995.

[11] GB 50487-2008, Code For Engineering Geological Investigation of Water Resources and Hydropower, The National Standards Compilation Group of the People's Republic of China, Beijing, China, 2008.

[12] Gb/T, "Technical standard for inspection of building structure," The National Standards Compilation Group of the People's Republic of China, Beijing, China, 2019.

[13] S. Lukasz, "Methodology for assessing the probability of corrosion in concrete structures on the basis of half-cell potential and concrete resistivity measurements," The Scientific World Journal, vol. 2013, no. 714501, 8 pages, Article ID 714501, 2013.

[14] ASTM C876-09, Standard Test Method for Corrosion Potentials of Uncoated Reinforcing Steel in Concrete, ASTM International, West Conshohocken, PA, USA, 2009.

[15] JGJ/T 152-2008, Technical specification for test of reinforcing steel bar in concrete, China Architecture \& Building Press, Beijing, China, 2008.

[16] J. W. Kyung, M. Yokota, V. Leelalerkiet, and M. Ohtsu, "Practical use of half-cell potential method for NDE of corrosion of reinforced concrete structure," Key Engineering Materials, vol. 270-273, no. Pt2, pp. 1638-1644, 2004.

[17] G. K. Glass, C. L. Page, and N. R. Short, "Factors affecting the corrosion rate of steel in carbonated mortars," Corrosion Science, vol. 32, no. 12, pp. 1283-1294, 1991.

[18] R. Parry-Davies and E. C. Knottenbelt, "Investigations into long-term performance of anchors in South Africa with emphasis on aspects requiring care," Ground Anchorages and Anchored Structures, vol. 3, pp. 384-392, 1997.

[19] R. B. Weerasinghe and R. W. W. Anson, "Investigation of the Long Term Performance and Future Behaviour of Existing Ground Anchorages," Ground Anchorages and Anchored Structures, vol. 3, pp. 353-362, 1997.

[20] Gb 5224-2003, Steel Strand for Prestressed concrete, Standards Press of China, Beijing, China, 2003.

[21] GB 50287-2016, Code For Hydropower Engineering Geological Investigation, China Planning Press, Beijing, China, 2016.

[22] B. M. Wei, Theory and Application of Metal Corrosion, Chemical Industry Press, Beijing, 1996.

[23] Fédération Internationale de la Précontrainte, Corrosion protection of Prestressed Ground Anchorages, Thomas Telford Ltd., Telford House, London, UK, 1986.

[24] GB/T 21447, Specifications for Steel Pipeline External Corrosion Control, Standards Press of China, Beijing, China, 2018.
[25] F. A. Champion, Corrosion Testing Procedures, Corrosion testing procedures, John Wiley \& Sons Inc., New York, NY, USA, 1952.

[26] ASTM G46-94, Standard Guide for Examination and Evaluation of Pitting Corrosion, ASTM International, West Conshohocken, PA, USA, 2005.

[27] T. Hopwood and J. H. Havens, Inspection, Prevention and Remedy of Suspension Bridge cable Corrosion Problems, University of Kentucky, Kentucky, 1984.

[28] S. Camo, "Probabilistic strength estimates and reliability of damaged parallel wire cables," Journal of Bridge Engineering, vol. 8, no. 5, pp. 297-311, 2003.

[29] J. S. West, R. P. Vignos, J. E. Breen, and M. E. Kreger, Corrosion Protection for Bonded Internal Tendons in Precast Segmental Construction, The University of Texas Austin, USA, 1999.

[30] J. Xu, Damage Evolution Mechanism and Remained Service Lives Evaluation of Stayed Cables, Tongji University, Shanghai, 2006.

[31] H. Xu, J. Wu, J. Huang, and D. Yan, "Study on grading evaluation of corrosion degree of existing stay cable steel wire based on corrosion pit parameters," Journal of China \& Foreign Highway, vol. 35, no. 6, pp. 148-151, 2015.

[32] K. Suzumura and S.-i. Nakamura, "Environmental factors affecting corrosion of galvanized steel wires," Journal of Materials in Civil Engineering, vol. 16, no. 1, pp. 1-7, 2004. 